\title{
THE ANALYSIS OF PROBLEM BASED LEARNING IN LEARNING MATHEMATICS SENIOR HIGH SCHOOL
}

\author{
Tiara Anggraeni, Akhsanul Inam, Marhan Taufik \\ Study Program Of Education Mathematics, Faculty of Teacher Training and Education, \\ University of Muhammadiyah Malang \\ tiaraanggraini121@gmail.com
}

\begin{abstract}
This study aims to determine the level of response, the level of motivation, student learning outcomes and learning process using Problem Based Learning on learning mathematics. This research is descriptive research where there is no manipulation only to describe and to analyze the data obtained. This research uses quantitative research methods with the subjects of the study which amounted to 33 people. Data collection techniques used include questionnaires, observations, interviews and tests. Data analysis used in this research is qualitative analysis technique and quantitative analysis. The result of the research indicates that the students response level to Problem Based Learning is high with the percentage of achievement of $72.02 \%$ and the students' motivation level with the percentage of achievement of $70.05 \%$. Student learning outcomes obtained using Problem Based Learning are quite satisfactory. With the percentage of achievement level reached $75.75 \%$. With the Minimum Exhaustiveness Criteria (KKM) score at the school is 75, so that all students meet the given KKM.
\end{abstract}

Keywords : Problem Based Learning(PBL), Level of responsiveness and motivation of student learning

\section{INTRODUCTION}

Progress on education world continue including the development of curriculum .The curriculum is all education experience given by the school to all students, either in school or outside school ( suryosubroto, 2004 ). The 2013 curriculum is the latest curriculum in which place students to become the learning centers and teachers only as facilitators. Curriculum 2013 aims to train student independence and improve students' activeness in learning process. The learning process in Curriculum 2013 teachers are required to act as motivators and facilitators so that students become learning centers. But not all teachers have such competence and lack of time to prepare for learning maturely is one of the obstacles faced (Alawiyah, 2015). In the development of curriculum also demanded teachers can adjust methods used.Based on the regulation of ministry of education and culture number 65 concerning about the standard process,the learning models primary for the implementation of 2013 curriculum are 
learning of inkuiry model, discovery learning model, projects based learning model and of problems based learning model (PBL).

Based on the research that has been done in the implementation of PBL there is increasing participation and activeness of student discussion. The average increase in the percentage of participation and activeness of the students' discussions indicates that there is a change in student behavior in teaching and learning activities to be better and there can be concluded that PBL is an effective learning model (Sholihah, 2010). In this study the selected learning model is Problem Based Learning (PBL). The Problem-Based Learning Model is one of the learning models of the scientific approach. Students are given a problem to solve themselves with the teacher only as a facilitator. The use of problems in relation to the real world allows students to understand the existing problems so that students more easily understand the material to discuss and create the learning process more effective.

Problem Based Learning is a learning that uses real-world problems as a context for students to learn self-confidence and problem-solving skills as well as to acquire knowledge and concepts that are the essence of the subject matter. This learning can provide an opportunity for students in exploreing, collecting and analyzing data so that students can be confident which includes: analysis, synthesis, and evaluation (Rusman, 2010). According to Pitadjeng the characteristics of problem-based learning as follows: a) the submission of questions or social problems; B) focusing on the interrelationship between the problem and the real world; C) the investigation is authentic; D) produce the product / work and display it; And e) cooperation among students in finding solutions (Pitadjeng, 2008).

\section{RESEARCH METHODS}

This study aims to analyze the results of treatment of research subjects. Because in this study there is no element of manipulation, which will only describe the results and analyze the data obtained. So research is descriptive research, that is a kind of research which attempts to describe phenomenon / event naturally. To get maximum result in this research using qualitative and quantitative approach. This approach has chosen because of data will of the process is the result of the problem based learning study results of students and data the interviews and questionnaire. 
In this study using quantitative research methods. This method can be interpreted as a research method based on positivism philosophy, used to examine the population or a particular sample, sampling techniques are generally done randomly, data collection using research instruments, data analysis is quantitative or statistical (Sugiyono, 2011). Research subjects or respodents of this research are students of class XI IPA 1 MAN Batu City. In class XI Science 1 consists of 6 male students and 27 female students with a total of 33 students. This study aims to collect data about the response, motivation and student learning outcomes. Therefore, at the time of the learning process conducted observations of student activities that focus on the response and motivation of students. After observation of the learning process will be conducted interviews and questionnaires to get data about student responses and motivation. Furthermore, the response and motivation data which is along with the student learning result data will be further analyzed.

Data processing response and more motivation using qualitative data analysis while data of student learning result which is quantitative data will be processed using quantitative / statistical data analysis. The data which is will be analyzed using quantitative data analysis (descriptive statistics) and qualitative data analysis. The data uses questionnaire, interview, observation and test, before the collection tool used was tested the validity and reliability of the questionnaire by using SPSS and there were obtained that each questionnaire is valid with the value (0.6319) and the results of the test reliability states that the reliable questionnaire with $>(0,970>0,4683)$.

\section{RESEARCH RESULTS AND DISCUSSION}

The results of this study obtained data response, motivation, learning outcomes and learning process. The result of questionnaire that has been processed obtained student response to learning mathematics using Problem Based Learning as in Table 1.

Table 1 : Analysis Results questionnaire of Student Response

\begin{tabular}{|c|c|c|c|c|c|c|}
\hline \multirow{2}{*}{ No } & \multirow{2}{*}{ Indicator of Student Response } & \multicolumn{4}{|c|}{ Result } & \\
\hline & & STS & TS & $\mathrm{S}$ & SS & \\
\hline 1 & $\begin{array}{l}\text { I am happy with learning mathematics } \\
\text { use PBL }\end{array}$ & $\begin{array}{c}0 \\
(0 \%)\end{array}$ & $\begin{array}{c}3 \\
(9 \%)\end{array}$ & $\begin{array}{c}24 \\
(73 \%)\end{array}$ & $\begin{array}{c}6 \\
(18 \%)\end{array}$ & 3,09 \\
\hline 2 & $\begin{array}{l}\text { The math lesson using PBL kept me } \\
\text { from sleepy during the lesson }\end{array}$ & $\begin{array}{c}0 \\
(0 \%)\end{array}$ & $\begin{array}{c}9 \\
(27 \%)\end{array}$ & $\begin{array}{c}20 \\
(61 \%)\end{array}$ & $\begin{array}{c}4 \\
(12 \%)\end{array}$ & 2,85 \\
\hline 3 & $\begin{array}{l}\text { The use of PBL made me motivated to } \\
\text { learn math }\end{array}$ & $\begin{array}{c}0 \\
(0 \%)\end{array}$ & $\begin{array}{c}8 \\
(24 \%)\end{array}$ & $\begin{array}{c}23 \\
(70 \%)\end{array}$ & $\begin{array}{c}2 \\
(6 \%)\end{array}$ & 2,82 \\
\hline 4 & $\begin{array}{l}\text { I can express my opinion well on the } \\
\text { PBL process }\end{array}$ & $\begin{array}{c}1 \\
(3 \%)\end{array}$ & $\begin{array}{c}6 \\
(18 \%)\end{array}$ & $\begin{array}{c}23 \\
(70 \%)\end{array}$ & $\begin{array}{c}3 \\
(9 \%)\end{array}$ & 2,85 \\
\hline
\end{tabular}




\begin{tabular}{llccccc}
\hline \multirow{2}{*}{5} & $\begin{array}{l}\text { PBL makes me more active in the } \\
\text { learning process }\end{array}$ & $\begin{array}{c}0 \\
(0 \%)\end{array}$ & $\begin{array}{c}6 \\
(18 \%)\end{array}$ & $\begin{array}{c}26 \\
(79 \%)\end{array}$ & $\begin{array}{c}1 \\
(3 \%)\end{array}$ & 2,85 \\
\hline \multirow{2}{*}{6} & $\begin{array}{l}\text { PBL makes learning maths more } \\
\text { interesting to learn }\end{array}$ & $\begin{array}{c}0 \\
(0 \%)\end{array}$ & $\begin{array}{c}7 \\
(21 \%)\end{array}$ & $\begin{array}{c}24 \\
(73 \%)\end{array}$ & $\begin{array}{c}2 \\
(6 \%)\end{array}$ & 2,85 \\
\hline \multirow{2}{*}{7} & $\begin{array}{l}\text { I am able to discuss with a group of } \\
\text { friends. }\end{array}$ & $\begin{array}{c}1 \\
(3 \%)\end{array}$ & $\begin{array}{c}1 \\
(3 \%)\end{array}$ & $\begin{array}{c}27 \\
(82 \%)\end{array}$ & $\begin{array}{c}4 \\
(12 \%)\end{array}$ & 3,03 \\
\hline \multirow{2}{*}{8} & I am able to apply work in groups & $\begin{array}{c}1 \\
(3 \%)\end{array}$ & $\begin{array}{c}4 \\
(12 \%)\end{array}$ & $\begin{array}{c}23 \\
(70 \%)\end{array}$ & $\begin{array}{c}5 \\
(15 \%)\end{array}$ & 2,97 \\
\hline \multirow{2}{*}{9} & $\begin{array}{l}\text { I can understand and solve problems } \\
\text { related to the environment to use PBL }\end{array}$ & $\begin{array}{c}0 \\
(0 \%)\end{array}$ & $\begin{array}{c}9 \\
(27 \%)\end{array}$ & $\begin{array}{c}23 \\
(70 \%)\end{array}$ & $\begin{array}{c}1 \\
(3 \%)\end{array}$ & 2,76 \\
\hline \multirow{2}{*}{10} & I can deduce the result of the solution & $\begin{array}{c}1 \\
(3 \%)\end{array}$ & $\begin{array}{c}8 \\
(24 \%)\end{array}$ & $\begin{array}{c}22 \\
(67 \%)\end{array}$ & $\begin{array}{c}2 \\
(6 \%)\end{array}$ & 2,76 \\
\hline \multirow{2}{*}{ Amount } & $\begin{array}{c}4 \\
(1,2 \%)\end{array}$ & $\begin{array}{c}61 \\
(18,3 \%)\end{array}$ & $\begin{array}{c}235 \\
(71,5 \%)\end{array}$ & $\begin{array}{c}30 \\
(9 \%)\end{array}$ & 28,8 \\
\hline
\end{tabular}

In addition to student response data also obtained data on student motivation in learning mathematics using Problem Based Learning as Table 2.

Tabel 2 : Analysis Results questionnaire of Student Motivation

\begin{tabular}{|c|c|c|c|c|c|c|}
\hline \multirow{2}{*}{ No } & \multirow{2}{*}{ Indicator of Student Motivation } & \multicolumn{4}{|c|}{ Result } & \\
\hline & & STS & TS & $\mathrm{S}$ & SS & \\
\hline 1 & $\begin{array}{l}\text { PBL on learning mathematics makes } \\
\text { me more skilled in solving } \\
\text { mathematical problems. }\end{array}$ & $\begin{array}{c}0 \\
(0 \%)\end{array}$ & $\begin{array}{c}4 \\
(12 \%)\end{array}$ & $\begin{array}{c}27 \\
(82 \%)\end{array}$ & $\begin{array}{c}2 \\
(6 \%)\end{array}$ & 2,94 \\
\hline 2 & $\begin{array}{l}\text { PBL encourages me to discover new } \\
\text { ideas. }\end{array}$ & $\begin{array}{c}0 \\
(0 \%) \\
\end{array}$ & $\begin{array}{c}8 \\
(24 \%) \\
\end{array}$ & $\begin{array}{c}22 \\
(67 \%) \\
\end{array}$ & $\begin{array}{c}3 \\
(9 \%) \\
\end{array}$ & 2,85 \\
\hline 3 & $\begin{array}{l}\text { I easily understand the material when } \\
\text { using PBL }\end{array}$ & $\begin{array}{c}0 \\
(0 \%) \\
\end{array}$ & $\begin{array}{c}7 \\
(21 \%) \\
\end{array}$ & $\begin{array}{c}23 \\
70 \% \\
\end{array}$ & $\begin{array}{c}3 \\
(9 \%) \\
\end{array}$ & 2,82 \\
\hline 4 & $\begin{array}{l}\text { Learning math using PBL makes me } \\
\text { better remember the material }\end{array}$ & $\begin{array}{c}0 \\
(0 \%)\end{array}$ & $\begin{array}{c}10 \\
(30 \%)\end{array}$ & $\begin{array}{c}20 \\
(61 \%)\end{array}$ & $\begin{array}{c}3 \\
(9 \%)\end{array}$ & 2,85 \\
\hline 5 & $\begin{array}{l}\text { I am enthusiastic about taking math } \\
\text { lessons using PBL }\end{array}$ & $\begin{array}{c}0 \\
(0 \%) \\
\end{array}$ & $\begin{array}{c}9 \\
(27 \%) \\
\end{array}$ & $\begin{array}{c}21 \\
(64 \%) \\
\end{array}$ & $\begin{array}{c}3 \\
(9 \%) \\
\end{array}$ & 2,85 \\
\hline 6 & $\begin{array}{l}\text { I am able to analyze the problems } \\
\text { easily given by using PBL }\end{array}$ & $\begin{array}{c}0 \\
(0 \%)\end{array}$ & $\begin{array}{c}10 \\
(30 \%)\end{array}$ & $\begin{array}{c}22 \\
(67 \%) \\
\end{array}$ & $\begin{array}{c}1 \\
(3 \%) \\
\end{array}$ & 2,85 \\
\hline 7 & $\begin{array}{l}\text { I feel math subject matter feels easier } \\
\text { when using PBL }\end{array}$ & $\begin{array}{c}0 \\
(0 \%)\end{array}$ & $\begin{array}{c}9 \\
(27 \%) \\
\end{array}$ & $\begin{array}{c}23 \\
(70 \%)\end{array}$ & $\begin{array}{c}1 \\
(3 \%)\end{array}$ & 3,03 \\
\hline 8 & $\begin{array}{l}\text { I do not feel bored with learning math } \\
\text { using PBL }\end{array}$ & $\begin{array}{c}1 \\
(3 \%)\end{array}$ & $\begin{array}{c}7 \\
(21 \%) \\
\end{array}$ & $\begin{array}{c}23 \\
(70 \%)\end{array}$ & $\begin{array}{c}2 \\
(6 \%) \\
\end{array}$ & 2,97 \\
\hline & Amount & $\begin{array}{c}1 \\
(0,3 \%)\end{array}$ & $\begin{array}{c}64 \\
(24,2 \%) \\
\end{array}$ & $\begin{array}{c}181 \\
(68,8 \%)\end{array}$ & $\begin{array}{c}18 \\
(6,7 \%)\end{array}$ & 22,54 \\
\hline
\end{tabular}

After processed data there can be concluded that students are very enthusiastic and getting less bored when the learning is engaging Problem Based Learning. Approximately $65 \%-70 \%$ of students agree that this makes students easier in remembering and understanding the material provided, and get more easily to analyze 
the problems they encounter. From the questionnaire it is found that the amount of = 22,54, 16< so that the student's motivation level uses High Problem Based Learning. By the high motivation of students to learn mathematics by using PBM addressed under the PBM can be used as an alternative that gives a positive influence on students.

Student learning outcomes data obtained from the value of LKS, the value of exercise questions and daily test, the three values obtained are processed into the final value with the final value $=$. The final value is presented in a histogram and processed using SPSS to find out the mean, median, mode, quartiles, standard deviations and variety.

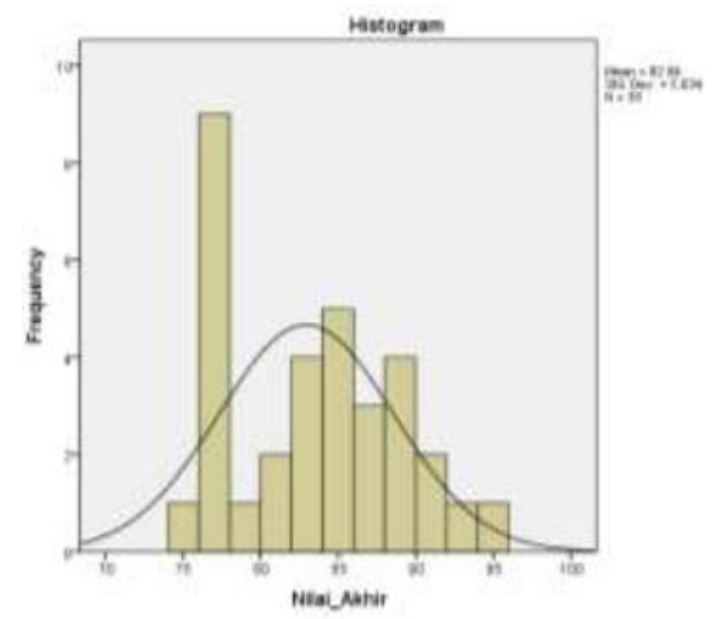

Picture1 : Final Student Value Histogram

Central Fixed Size Value, Location and Distribution of Final Value Data is obtained by using SPSS application, concentration size value, location and data spread can be seen in Table 3

Table 3 : Centralization Measures, Location and Spread of Final Values

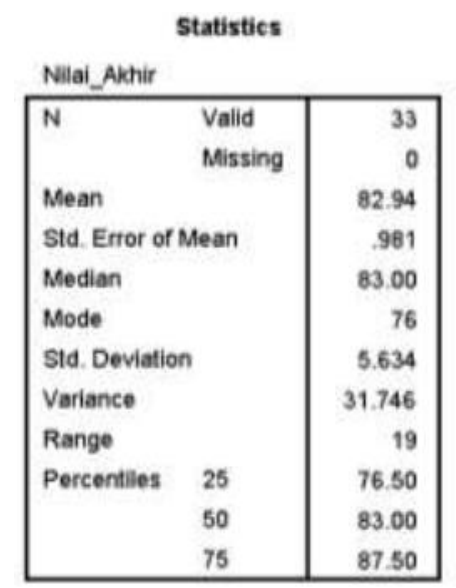


From the table obtained that the average final value of 33 students is equal to 82.94 with standard error of SPSS of 0.981 or error rate of 0.012 . The median value score of the student's final score is 83 and the mode or value of the most students is 76 . So that it can be concluded that the student's frequency is the most to get the value of 76 . For the location size, the quartile 1, quartile 2 and quartile 3, Respectively are 76.5.83 and 87.5. The size of the data distribution is the range, the variant and the standard deviation of the data, the range or range from the highest to the lowest is 19 . So the value range of 33 students is 19 , the higher the range of students the more the student's score. Description of variant is how the data scattered or spread and obtained the value of the variant of the data is 31,7 . The variance value which is regarded to be low because it is still close to zero. With a low variance value it can be concluded that the data or values treated are not too different from each other or the rate of spread is low. Similar to variants, standard deviation is a way of determining how data spreads and how close individual data to the mean (average) point of a sample. The standard deviation value obtained is 5.36.

Learning activities held 4 times meetings (4 times 90 minutes), At the first meeting students form a group and started collecting data according to the LKS has been given. The existence of guidance in the LKS facilitates students to do it with a little help from the teacher. At the second meeting the activity was to continue the LKS until completion and students were required to prepare as well as to present the results of the LKS. At the second meeting the students worked on the LKS about finding the mean, median, mode, quartile, deviation and range for group data. At the third meeting students are given the opportunity to present the LKS in front of their friends. Seeing that the time constraints, from 10 groups there were only 2 groups who could present the results of completion of the LKS. After completing the presetation activities the teacher a little additional material by presenting formulas and sample questions in order to facilitate students to understand more about the material being discussed. After completing the materials, students were reminded of the next meeting of the students Daily tests.

Descriptive research in class XI IPA 1 MAN Batu City Lesson 2016/2017 results of this study indicate that with the use of Problem Based Leraning student responses and student motivation on learning mathematics is considered high. Data response and motivation of students obtained from the questionnaire, observation and interview. Based on the results of the questionnaire of students $72.02 \%$ and student motivation of 
$80.5 \%$, the data on the research were supported by the observations in the learning activities and interviews of some students.

Based on the research that has been done in the implementation of PBM to increase the participation and activeness of student discussion shows that there is an increase of student participation from $59,11 \%$ (pre cycles) to $80 \%$ (end of cycle II) and student activeness improvement from $50,62 \%$ (pre cycle ) to $77.3 \%$ (end of cycle II). The average increase in the percentage of participation and activeness of the students' discussions indicates that there is a change in student behavior in teaching and learning activities to be better and there can be concluded that PBL is an effective learning model. Implementation of this learning model makes students more familiar with the matterial that are given subject matter given by the teacher, because the students are required to work with a group of friends to explore the has been give that material by the teacher and presenting it in front of the class (Sholihah, 2010).

Based on the students learning activities there were obtained the group score, tasks score and remidial score to where futher processed into the final score. With KKM 75 all grades of students of class XI IPA 1 complete with an average of 82 . Based on the data obtained student learning outcomes have the percentage of students mastery of students score is $100 \%$ and the value above 76 (mode) of $75.75 \%$. With a percentage of 75.75\% which is classified as high can be said Problem-Based Learning provides satisfactory learning outcomes.

Based on the research that has been done in the application of PBL model in Class III SDN II Jeruk Surabaya showed that there is an increase in student learning outcomes from $35.5 \%$ (pre cycles) to $85.36 \%$ (end of cycle II). According to the rahma and tjatik the activities of teachers using the PBL progress and achieve the best results, the most important matter to note is to establish student activeness through group discussion and deepen into the memories of students about the material learned (Malik \& Mudjiarti, 2014). From the previous research on the use of Problem Based Learning on the material opportunities obtained data such as Table 4.

Tabel 4 : Results of PBL Use on the Opportunity Material

\begin{tabular}{lll}
\hline Average end value & 87,42 & 82,16 \\
\hline Amount students are complete the study & 27 & 21 \\
\hline Amount students are not complete the study & 4 & 10 \\
\hline Percentage of many students who complete the study & $87,1 \%$ & $67,7 \%$ \\
\hline Exhaustiveness of learning in classical & complete & Not complete \\
\hline
\end{tabular}


From Table 4 shows that the percentage of many students who succeeded in learning that belong to those who get learning with the model of learning based on the problem group (experimental class) are $87.1 \%$, it shows the students who get learning with the model of learning based on the problem The classical thoroughly. While the percentage sum of students who succeeded in learning that belong to classical problem based leraning (control class) are 67,7\%, it indicates the students who get classical problem based learning have not succeeded classically (Katiasri, Nusantara, \& Qohar, 2012).

Seing from the result of this research and some previous studies study results students are showing the result of mutual support. This showed that using learning based problems the average study results obtained of students 80-85\% compared to learning conventional.

\section{CONCLUSION}

Based on the results of research and discussion that has been described previously, the use of Problem-Based Learning Model (PBL) in class XI IPA 1 MAN Batu City academic year 2016/2017 in Mathematics learning can be concluded that the student response to PBL is high with the percentage of achievement of $72,02 \%$. Students are able to follow the learning process well and provide a positive response that supports the course of the learning process. The level of student motivation to PBL is high with the percentage of achievement of 70,05\%. By the high level of student motivation shows that with the use of Problem Based Learning to make students more motivated and enthusiastic to follow the learning of mathematics.

Student learning outcomes which are obtained using Problem Based Learning are quite satisfactory. With the percentage of achievement level reached $75.75 \%$. The score which is by students on average is quite satisfactorily found in the range 75-80. With the Minimum Exhaustiveness Criteria (KKM) score at the school is 75 , so that all students meet the given KKM. Learning activities held 4 times meetings (4 times 90 minutes), at first meeting students did the data collection, second meeting students started to processed the data, the third meeting students presented LKS and worked on the exercise in order to examine material understanding and the last meeting students conducted review and tests.

The data have been processed obtained from questionnaires, interviews, observation and written tests. The questionnaire data to spread has been through the process of 
validity and reliability test, where the questionnaire data is supported by interview and observation data. Writing test data is used to determine student learning outcomes in the form of values with a range of 0-100. Some suggestions, responses and learning motivation denote the main key for students during activities in the classroom and gaining optimal learning outcomes. Learning model used in learning activities greatly affect to student's learning responses and motivations that also affect student learning outcomes. In addition to the factor learning model that is used factor also influential teachers. Teachers should use more innovative and varied media materials when implementing math learning. So that students are more motivated to follow the learning, so that student learning outcomes can also increase.

Not only teachers, students also affect the success of a learning. Students should not be dependent on the material which is provided by the teacher only, but also more actively seek material information from other sources so that will increase students' insight in solving the problems faced. In addition students should be more active in group discussion activities as well as during group presentations.

\section{REFERENCE}

Alawiyah, Faridah. 2015. Teachers Readiness in Curriculum Implementation 2013. Kajian Singkat VI(15)

Katiasri, Nusantara, \& Qohar. 2012. Problem-Based Learning in Simple Event Opportunity In Class Ix Smp Negeri 3 Tulungagung.

Malik, R. \& Mudjiarti, T. (2014). Application of Problem Based Learning Model to Improve Learning Outcome of Size and Square Rectangle of Class III SDN Jeruk II Surabaya.

Pitadjeng. (2008). Effectiveness of Problem-Based Learning (PBM) Nuanced JigsawAssisted Learning Cd Graduate Program.

Rusman. (2010). In Model - The Learning Model develops Teacher professionalism. Jakarta: PT. Raja Grafindo Persada.

Sholihah, I. (2010). Application of Problem Based Learning Learning Model (PBL) to Increase Participation and Activity Discussion of Students in Biology Learning Class VII SMP Negeri 2 Surakarta.

Sugiyono. (2011). Research Methods Quantitative, qualitative and $R \& D$. Bandung: Alfabeta, 90.

Suryosubroto, B. (2004). Education Management In School. Jakarta: PT. Rieneka Cipta. 